\title{
An Ethnoarchaeological Approach to the Seasonality of Historic Cree Sites in Central Québec
}

\author{
CHRISTOPHER C. HANKS ${ }^{1}$
}

\begin{abstract}
Determining site seasonality in the eastern Canadian Subarctic is crucial to the interpretation of settlement patterns of both prehistoric and modern hunters and gatherers. Ethnoarchaeology provides a conceptual framework through which ethnographic informants are used to develop an archaeological podel of site seasonality for recent historic sites. This research has led to the development of an hypothesis that structure form, hearth type, and floor preparation can be used to predict site seasonality.
\end{abstract}

Key words: ethnoarchaeology, Cree, Naskapi, Montagnais, land use, structure types

RÉSUMÉ. La détermination de l'état saisonnier d'un site dans l'est de la région subarctique canadienne est d'une importance capitale dans l'interprétation des types d'établissement chez les chasseurs et les cueilleurs autant préhistoriques comme modernes. L'ethnologie nous présente un cadre conceptuel dans lequel des informateurs élaborent un modèle archéologique de l'état saisonnier du site dans le cas de sites historiques récents. Cette recherche a entraîné la mise au point d'une hypothèse selon laquelle la forme de la structure, le type de foyer et la préparation du plancher peuvent aider à prédire l'état saisonnier du site.

Mots clés: ethnoarchéologie, Cri, Naskapi, Montagnais, utilisation du terrain et types de structures

Traduit pour le journal par Maurice Guibord.

\section{INTRODUCTION.}

Archaeological survey work in the Caniapiscau Reservoir (Fig. 1) has been concerned with both prehistoric and historic changes in settlement systems and resource utilization (Denton et al., 1981a:1). As a part of that research, historic Native sites recorded by the survey have been examined as a means of delineating the variation in settlement patterns of identifiable historic groups in the region. Since the inception of the research in 1976, principal investigator David Denton has included local Native hunters among the survey crews (1977 and 1978). This practice was continued when the author supervised the survey for the 1978 field season, while Denton began excavation on Lac Delorme.

The Caniapiscau River rises in Central Québec-Labrador and flows north to the Arctic Ocean at the base of Ungava Bay. Dams built at Lac Duplanter as a part of the James Bay Project resulted in a large section of the upper river being flooded and the water being diverted west from the Caniapiscau into the La Grande River system. In preparation for the inundation, archaeological research to record prehistoric and historic sites in the Caniapiscau Reservoir was carried out by the Service d'Archéologie et Ethnologie, (now called Service du Patrimoine Autochtone), Ministère des Affaires culturelles, Gouvernement du Québec.

In 1978, a subsurface and surface archaeological survey was completed on three series of lakes (Fig. 2) near Lac Caniapiscau (Ice Bound, Male Otter, and Tournon) and the east branch of the proposed reservoir northeast of Lac Caniapiscau (Hanks, 1979).

The team surveying the Caniapiscau during the 1978 field season included the Rabbitskin family from the Cree village of Mistassini Post, Québec. Sam Rabbitskin's trapping territory lies in the southwest portion of the reservoir basin. The crew comprised Sam, his nephew Williams Rabbitskin, Williams's son Alan, and the author. Our camp was maintained by Williams's wife Betsie and his niece Sally Blacksmith.

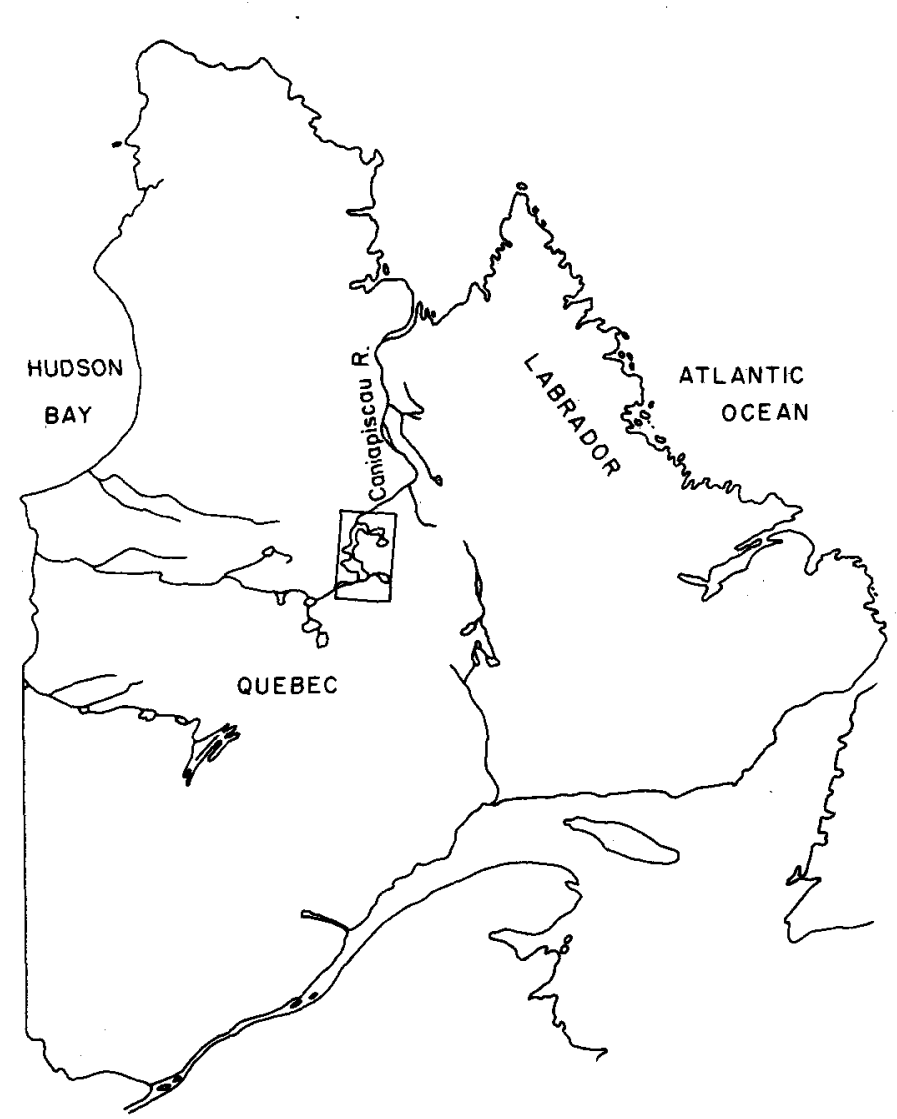

FIG. 1. The Caniapiscau Reservoir area, centre of map.

In the field, the survey crew provided a good deal of information about the sites that we located. Often they knew who had inhabited them, and what certain structure designs, floor modifications, and hearth types meant in terms of the seasonal settlement pattern of historic Amerindian occupations in the reservoir. 


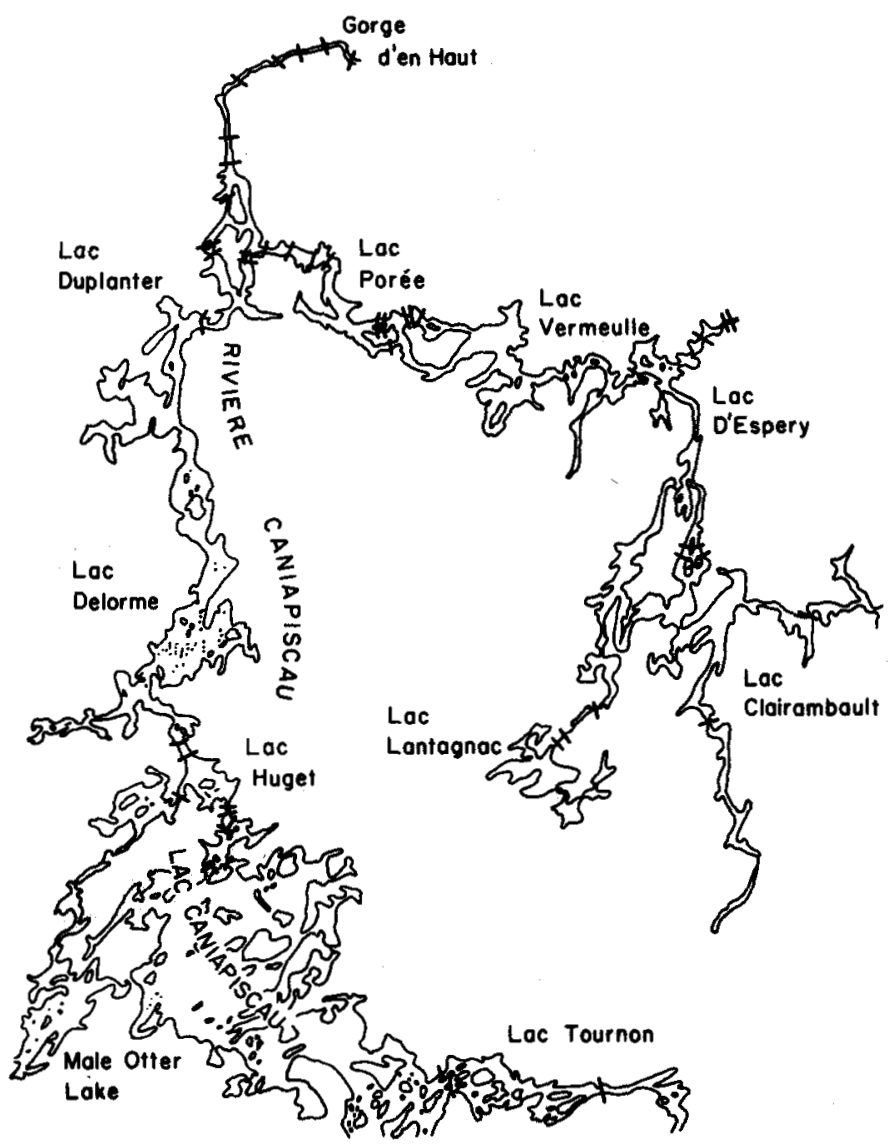

FIG. 2. The study area.

In late historic times, the western half of the Caniapiscau Reservoir has been inhabited by eastern Cree from Mistassini, Québec, while the eastern branch was occupied by Montagnais and, to the north, Naskapi now living in Schefferville and Sept-Îles, Québec. The presence of these three groups within the reservoir in recent historic times provided an opportunity to examine possible differences in their settlement patterns. This analysis will examine the relationship between historic and prehistoric sites and the determination of seasonality for historic Amerindian occupations in the Caniapiscau Reservoir.

\section{METHODOLOGY}

Ethnoarchaeology, or the application of archaeological methods to ethnographic data, is an extremely useful technique in regions such as the Arctic and Subarctic where vast areas are still exploited by Native people. The use of ethnographic data can improve the quality of analogies made about past behaviour, through the observation of both prehistoric sites in their present condition and recent sites which may represent similar behavioural processes or responses. According to Binford (1978), the interpretation of prehistoric human behaviour requires the assignment of meaning to temporally arranged forms, or site patterning. Before any statement can be made about change in the prehistoric record, meaning must be assigned to "the contemporary facts of the archaeological record..." (Binford, 1978:1). The ethnoarchaeological approach was applied to the Caniapiscau survey in order to ex- amine J.V. Wright's (1968:66) assumption that the direct historic approach could be used for establishing a culture history in the boreal forest. The direct historic approach is a logical method for working from historic to prehistoric sites. Historic sites are first located and then, if possible, connected to an identifiable tribe. Second, the cultural complexes of the site are determined. Third, sequences are carried backward in time to the protohistoric and prehistoric sequences and cultures (Steward, 1942:337). In applying the direct historic approach to the Caniapiscau a second set of assumptions has to be accepted. These assumptions are that historic occupations were placed to accommodate "the greatest ecological advantage in terms of ease of approach, water resources ... and availability of wild resources" (Pilling, 1968:153). In addition, the same criteria which applied to historic sites were assumed to be valid for prehistoric sites.

In the eastern Subarctic, seasonal environmental variability is an important factor in site location. In summer, muskeg bogs on the Canadian Shield effectively limit human movement to river and lakes. During winter when bogs are frozen, people are able to travel more extensively. Thus, prior to the survey, it was assumed that there would be an extreme variation between the locations of the three classes of sites: 1) locations occupied during periods of open water (late spring and early fall);2) areas where access was practical only when the muskeg was frozen; and 3) locations that were accessible, dry, and near resources that could be used year-round, e.g. a dependable fishery.

\section{DISCUSSION}

Based upon the above geographical considerations, my assumption was that sites would be located in areas protected from west and northwest winds, with a $<7 \%$ slope except during periods of deep snow, and away from boulder-strewn areas. It was also predicted that summer sites would not be on muskeg. These criteria were modified by Williams Rabbitskin as to site location in specific seasons. According to Rabbitskin, winter camps are placed in large, tall, dense stands of trees (approximately $25 \%$ average forest density). The sites are sometimes dug into the sides of hills, but more frequently benches on hillsides are used. Sites are picked primarily for survival and comfort, i.e. to provide protection from west and northwest winds (normally on the northern or western shores of rivers and lakes), firewood, and a surface free from rocks. Favoured occupation zones are not necessarily located in areas of good trapping potential but they are in close proximity to such regions. For example, Sam Rabbitskin stated that while the small lakes to the north of Lac Tournon (Fig. 2) are good places for hunting and trapping, the area is low, wet, and lacking in cover, and thus unsuitable for fall or winter occupation. Therefore, when trapping that area, he frequently lives south of Lac Tournon.

When spring camps are chosen, the selection criteria are modified to include nearby open water early in the season where waterfowl will gather. In spring, the use of geographical features for protection from the elements is not as crucial, so frequently sites are placed in dense groves of trees which 
provide cover, firewood, and boughs for the lodge floors. There is one exception to the rule of finding sites sheltered from the winds, "the summer when breezy spots are sought for the protection they give from mosquitos and black flies..." (Rogers, 1963:226).

When these hypotheses were compared with the actual survey data, the most significant feature to emerge was the actual configuration of the site. As predicted, it was discovered that locations with high density of exposed cobbles and small boulders, which had to be cleared away before use, were not chosen for occupation even if they had other favourable characteristics. On the northwest shore of Male Otter Lake, which is protected by a low hill providing excellent shelter from prevailing northwest winds, the ground surface has extensive boulder cover and accordingly no sites were found there. A similar configuration is present at the southeast end of Lac D'Espery (Fig. 2), but there the ground is largely stonefree. Four sites were located along a $0.8-\mathrm{km}$ survey segment in that area.

Of the 131 sites located by the survey, the majority had a southerly exposure. Protection from the prevailing northwest wind was most frequently provided by tree cover $(25 \%)$, as only $10 \%$ of the winter occupations and $4 \%$ of the sites occupied during frost-free months were sheltered by hills or beach ridges. Thus, differences in type of protection do not appear to be a significant factor in determining the seasonality of sites, because trees provide adequate cover in most cases.

Sam and Williams Rabbitskin maintained that the height of tree stumps cut near the site serve as an indicator of the seasonality of recent historic sites. According to the Rabbitskins, in snow-free seasons trees are cut low to the ground ( $<1 \mathrm{~m}$ above ground), while in winter trees are cut progressively higher depending on snow depth. In combination with lodge type, floor preparation, and hearth type, stump height appears to be a useful indicator of snow-covered versus snow-free months. A total of $21 \%$ of the sites investigated during the 1978 field season had tree stumps that could be used to assist in determining site seasonality. Of those, $82 \%$ indicated a winter occupation.

When comparing the distance from water for winter and summer sites, it was found through the use of a T-test that there is a statistically significant difference between summer and winter occupations $(T=0.5)$. In general, summer sites have a mean distance of $19 \mathrm{~m}$ from the nearest lake or large river and winter occupations have a mean distance of $22 \mathrm{~m}$. This variation may be accounted for by the fact that winter sites are placed to maximize shelter for the site. There is no statistically significant difference between seasonal occupations in terms of elevation above the water source.

Despite the evidence that winter camps are located slightly further inland than summer camps, it is clear that major bodies of water play a significant role in site selection the year round. According to Sam and Williams Rabbitskin, camps are always located close to a place with reliable net fishing because fish are the most dependable resource available to people in the Caniapiscau area. Only one site was found during the entire survey that was in a position where, because of its location on a section of very shallow water in the river $(<1 \mathrm{~m})$, winter net fishing and angling were impossible. Under normal circumstances, depths of $2-6 \mathrm{~m}$ of water within $100 \mathrm{~m}$ of shore are sought, depending upon the depth of the ice. Prior to the introduction by fur traders of steel ice-chisels and needle bars, ice thickness would have been much more significant than it is today. Of primary concern when setting a net under the ice is that enough water is present so that the net does not freeze to the undersurface of the ice. The early French explorers reported that, at the time of contact, the Huron were trading gill-nets to eastern subarctic groups (Moussette, 1979:103-104). It is not known, however, whether these nets reached the Caniapiscau region. As a result, the suitability of gill-net fishing as a criterion for locating prehistoric sites may be inappropriate.

The Caniapiscau study area is in a region of overlap between the Cree from Mistassini and Fort George, the Naskapi formerly of the old Fort Mackenzie band, now at Schefferville, and Montagnais formerly from the Seven Islands band who now live in Schefferville. Because of this mixing of tribal groups within the study area, the evaluation of structure styles by the Rabbitskins within the Cree taxonomy of dwelling types and functions may not always be the same as they would be described by the Montagnais or the Naskapi. This is particularly true in the most northeastern portion of the study area on Lac Vermeulle, Lac D'Espery, and Lac Clairambault (Fig. 2), which neither Sam nor Williams had visited prior to the 1978 survey. As a result, there has been some debate regarding whether it is appropriate to use Cree terminology when describing variations in structure types identified by the Rabbitskins, or if a more neutral English terminology should be applied. After careful consideration, I chose to continue to utilize the Cree terminology as opposed to switching to English terms. The proposed change would not have eliminated any bias incurred by the Rabbitskins' interpretation of structure types in the northeastern portion of the study area. Through retaining the Cree terminology, the basic assumptions made in this paper can be more clearly identified and tested in the future. The eventual publication of Montagnais terms should open the way for comparative studies of structure type terminology to be done as more complete syntheses are compiled for the region.

\section{Structure Type}

Not all structure types are indicative of seasonality. Structure types were identified on the basis of the pattern and size of collapsed lodge poles. The miicwaap or "conical skin or bark teepee" (Tanner, 1978:24), which comprises 57\% of the 130 dwellings that were identified by the survey, is represented during all seasons. Although in recent years the miicwaap has not been used at Caniapiscau, it was by far the most popular lodge type before the maki or square wall-tent was adopted. The maki is the lodge type most frequently used by the Cree at Caniapiscau today and formed $17 \%$ of the identified historic dwellings found by the 1978 survey.

With the exception of the miicwaap and the maki, traditional lodge styles are indicative of season. The waasakumik com- 
prised $13 \%$ of the sample of identified dwellings. The frame of this house type is constructed by building a foundation wall of snow and then placing short poles into the top of the snow wall. The ridge pole is supported inside the ovoid snow-andpole wall by two uprights forked at the top. "The dwelling seems to be linked to the use of canvas, and refers to a frame over which canvas is thrown..." (Tanner, 1978:25). According to Tanner, some Cree mentioned that they had changed from the miicwaap to the waasakumik (1978:24). Because snow plays an integral part in building the house wall of the waasakumik, its use only occurs during periods of snow cover.

The saaputwaan, a multiple-family dwelling, is an elongated lodge constructed of poles, canvas and/or hides, and bark, with a door at each end. Miicwaaps and saaputwaans were the most common multiple-family dwellings identified by the survey. Of the four saaputwaans enumerated, it was assumed that all were three-family units with one hearth or stove per family. The one family/one hearth assumption has also been noted by Tanner among the Cree (1980:76). All the saaputwaans found were in areas most frequently occupied by the Montagnais. Although a variation of the dwelling is described by Rogers (1964:9) for the Mistassini people, Alan Rabbitskin, in consultation with Williams and Sam, stated that the saaputwaan is not common among the Mistassini Cree and is a lodge used more often by the Montagnais and Naskapi. Sam Rabbitskin maintains that the saaputwaan was used by the Cree primarily in the fall and occasionally in the spring when people came together to exploit a large resource such as a fishery, or for a communal caribou hunt. In areas primarily inhabited by the Montagnais and Naskapi, the saaputwaan's major use is as a communal dwelling during the caribou hunt (Denton, pers. comm. 1978).

The sciikumik, or moss-covered lodge, is built in the fall to serve as a base camp for the early winter hunt. Typically, the sciikumik is square or rectangular at the base with a sunken floor and a low log foundation wall. The top is a conical pole frame covered with moss or sod.

Small sweat lodges (mean diameter of $0.5 \mathrm{~m}$ ) were found in conjunction with two camps identified as winter residences by the Rabbitskins. According to Williams Rabbitskin, this small variation of the sweat lodge is for use by one person with an inexplicable pain and is called an atutson.

The final type of structure surveyed is called an acreeskun by the Cree. According to Sam Rabbitskin, it is used as a temporary crypt until bodies can be moved in the spring to be taken to their home villages for burial. An acreeskun located on Lac Lantagnac in 1978 was a low log structure approximately $3 \mathrm{~m}^{2}$, covered with a flat roof of small logs and brush. Because the top logs were still in place, Sam Rabbitskin speculated that the bodies had never been removed.

In all, the collapsed remains of seven distinct types of structure were recorded. Of those, miicwaaps and makis are used in any season. Waasakumiks are primarily used in the winter after a heavy snowfall. The sciikumik is built in late fall and used into midwinter. The saaputwaan is used during the winter caribou hunts by the Montagnais, Naskapi, and Cree, and during the spring and fall fishing seasons by the Cree.
Finally, the atutson is used year-round and the acreeskun is a winter structure. Both the atutson and acreeskun serve specialized socio-religious functions and are not part of the regular pattern of dwellings.

\section{Hearth Type}

Two main types of hearths were identified for historic sites and may allow for the identification of site seasonality. The winter hearth is characterized by a single large, flat boulder. These boulder hearths are stationary rocks that normally protrude $0.3-0.5 \mathrm{~m}$ above the ground. The lodges are built over them on packed-snow platforms covered with boughs. The surface area of a winter boulder hearth is usually between 0.5 and $1 \mathrm{~m}^{2}$. Approximately $10 \%(\mathrm{~N}=47)$ of the hearths recorded are of the stationary-boulder type. A variation of the winter hearth type occurs when the boulder is intentionally fire-cracked and the fragments are used as hearth stones on the original boulder surface.

The other frequently found hearth type, used predominantly when the ground does not have snow cover, is constructed with small rocks and boulders $10-40 \mathrm{~cm}$ in diameter. There are two types of loose stone hearths: 1) the platform hearth, in which the top layer of stones rises above the lodge floor; and 2) a hearth pavement in which the surface of the top layer of rocks is flush with the surface of the house floor. Both variations of this hearth type average from 0.5 to $1 \mathrm{~m}$ in diameter. Of the hearths sampled in the 1978 survey, $90 \%$ were of this type.

\section{Lodge Floor Preparation}

The preparation of a lodge floor can be diagnostic of the season of use. Three distinct types of floor preparation are found in the Caniapiscau: unprepared; levelled, where the ground surface has been flattened; and semi-subterranean, situated at a depth of $10-25 \mathrm{~cm}$ below the surface. Of the 70 floors identified in the survey, 55\% were unprepared, $27 \%$ were levelled on the surface and $17 \%$ were semi- subterranean. An unprepared floor, according to Sam Rabbitskin, means either that the occupation was used only for a short time or that it was constructed after the ground froze in late fall. A levelled floor is a strong indicator of a dwelling built when there was no frost. Semi-subterranean dwellings, according to Sam and Williams Rabbitskin, were built only between late September and late October in preparation for use through midwinter.

Of the three variations of floor preparation, the semisubterranean is the most diagnostic of seasonality. Of the 19 levelled floors examined, $68 \%$ were determined to have been frost-free occupations on the basis of other evidence (i.e. low stumps and multi-stone hearths). The remaining $32 \%$ were assigned to winter occupations on the basis of a combination of high tree-stump cuts and/or large-boulder hearths. Of these factors, boulder size appears to be the more diagnostic (Table $1)$. 
TABLE 1. Characteristics of sites occupied during snow-covered vs. snow-free periods

\begin{tabular}{|c|c|c|}
\hline Period of Occupation & $\begin{array}{l}\text { Location Characteristics } \\
\text {-tree cuts }>1 \mathrm{~m} \\
\text {-boulder hearths } \\
\text {-semi-subterranean floors } \\
\text {-unprepared floors } \\
\text {-mean distance of } 22 \mathrm{~m} \\
\text { from water } \\
\text {-access to gill-net fishing } \\
\text {-protection from } \mathrm{NW} \text { wind }\end{array}$ & $\begin{array}{l}\text { Structure Types } \\
\text { miicwaap } \\
\text { maki } \\
\text { waasakumik } \\
\text { saaputwaan } \\
\text { sciikumik } \\
\text { atutson } \\
\text { acreeskun }\end{array}$ \\
\hline Late spring to late fall & $\begin{array}{l}\text {-tree cuts }<1 \mathrm{~m} \\
\text {-pavement hearths } \\
\text {-unprepared floors } \\
\text {-levelled floors } \\
\text {-mean distance of } 19 \mathrm{~m} \\
\text { from water } \\
\text {-access to gill-net fishing }\end{array}$ & $\begin{array}{l}\text { miicwaap } \\
\text { maki } \\
\text { atutson } \\
\text { saaputwaan }\end{array}$ \\
\hline
\end{tabular}

\section{RELATIONSHIP OF HISTORIC TO PREHISTORIC SITES}

The effectiveness of the survey technique used in the Caniapiscau was demonstrated in locating historic occupations. Where the format failed, however, was in the location of prehistoric sites (defined by the presence of lithic artifacts and debris). Of the 131 sites recorded on the 1978 survey, 17 were prehistoric and of those only two sites were multi-component historic-prehistoric occupations.

Based upon the total mean scores for distance from water and elevation above water, it was discovered (T-test at the 0.5 level) that prehistoric sites were significantly further from the nearest major water body and were higher in elevation than the historic sites. Prehistoric sites had a mean distance of $30 \mathrm{~m}$ from water whereas historic sites had a mean range from 19-22 $\mathrm{m}$. Similarly, the mean elevation of historic sites was only 1.2 $\mathrm{m}$ while the mean elevation for prehistoric sites was $3 \mathrm{~m}$ above lake or river level. A number of explanations are possible for this phenomenon, including sampling error and settlement pattern changes.

With respect to using ethnoarchaeological research as a method of instituting the direct historic approach, a problem arises. The survey plan for 1978 was based upon the assumption that historic occupations were placed to accommodate "The greatest ecological advantage in terms of ease of approach, water resources... and availability of wild resources..." (Pilling, 1968:153). As a corollary to that assumption, it was postulated that a relationship existed between the locations of historic and prehistoric sites. The differences demonstrated between historic and prehistoric sites in terms of distance from water and elevation above water raise serious questions about the validity of assuming similarity of geographic situation for both types of sites. The 1978 survey demonstrated no significant degree of overlap between historic and prehistoric Amerindian occupations in the survey area (Hanks, 1979:10). Though this may reflect a divergence between the prehistoric and historic periods in the Caniapsicau area, it could also be a result of other factors. Due to the vastness of the region examined, the sampling strategy was judgmental as opposed to probabilistic. As a result, there are un- doubtedly sampling errors. Further, historic sites are often visible on the surface while prehistoric sites are normally found only by intensive subsurface testing, and consequently, more historic sites are always found than prehistoric ones.

\section{CONCLUSIONS}

Structure type, hearth style, floor modification, height of tree cuts, and distance from water have been identified as general criteria of seasonality. In making predictive statements, these criteria were used in various combinations as the strength of their individual inferential possibilities has not been properly tested, though stump height and floor preparation would seem to be the strongest indicators. Direction of exposure, site elevation, and orientation of base camps to fisheries can be viewed as year-round constants.

These finds modify certain of the predictions made in the hypotheses constructed before the survey. First, it was assumed that the greater mobility offered by snow cover in the winter would lead to winter camps being located away from major water bodies. Survey data indicated that both winter camps and those maintained during open-water season were located close to the major water bodies. According to our informants, camps in all seasons were established to exploit nearby fisheries.

Second, our literature search and interviews with Mistassini Cree people prior to entering the field suggested that winter sites would frequently be in close proximity to geographic cover (e.g., hills, beach ridges, moraines, or eskers). In fact only $10 \%$ of the winter sites surveyed depended on a geographical feature for protection from prevailing winds. Typically, sites occupied in all seasons depended primarily upon forest cover for protection.

Survey data collected from 131 sites in 1978 are not sufficient to build an effective model for defining seasonal variation based upon geographical and geological circumstances. At the present time, seasonal variation must be determined on an individual site basis by structure type, hearth style, floor modification, and stump height. According to the Cree informants, seasonality can normally be determined from a combination of these factors.

Accurate predictive statements can be made about site location in general, placing higher priority upon northern and western shores of lakes, heavy forestation, boulder-free locations with a view, and a water depth of several metres close to shore. Despite the fact that the majority of sites will be found within these circumstances, our research strategy did not adequately sample areas of lower probability that ethnographic evidence indicated would not have been frequently occupied. When these regions are brought into the analysis, our conceptions of seasonality may be further modified.

When we consider the results of the 1978 Caniapiscau survey against the preliminary goal of that study, which was to test the application of the direct historic approach to survey data in the Caniapiscau region, it becomes apparent that the types of questions asked and the data that were recorded did not allow the concept of the direct historic approach to be ad- 
dressed. At an ethnographic level, precise boundaries for the Cree, Montagnais, and Naskapi are still being established in the region. Though lodge forms, hearth types, and methods of floor preparation may vary slightly between cultural groups in the region, the 1978 survey recorded no patterning in the variations in form that might be readily culturally identifiable. Despite this observation, the author is in agreement with Charles Martijn, who maintains that more work is required before the possibility can be discounted that ethnicity can be determined from inter- and intra-site variability (Martijn, pers. comm. 1982). Finally, there is not yet adequate evidence to infer a correlation between historic and prehistoric settlement patterns in the region.

This paper has demonstrated that it is possible to test hypotheses about historic site distribution and form, which can be related to factors of site seasonality. However, this information does not necessarily provide a basis for the application of the direct historic approach as a methodology for linking historic cultures with prehistoric ones. The information generated about site patterning as it reflects human behavioural responses to seasonality, social organization, and resource availability is best related to the prehistoric record in terms of possible analogies to historic behaviour rather than in terms of a causally related chain of events between the historic and prehistoric periods. Finally, it must be stressed that there is an inherent danger in placing too much emphasis upon the use of historic models in predicting prehistoric behaviour; that is, too close an adherence to the model may obscure systematic differences between the historic and prehistoric periods.

\section{ACKNOWLEDGEMENTS}

I would like to express my gratitude to David Denton, principal investigator of the Caniapiscau Reservoir Project, for allowing me to use material from the 1978 archaeological survey for this paper. Also, I wish to thank Charles Martijn and George Barre of the Service du Patrimoine Autochtone, Ministére des Affaires culturelles, for permission to publish this material.

A note of sincere thanks is due to Sam, Williams, and Alan Rabbitskin, who were not only my field crew but also my patient informants. I would also like to acknowledge Sally Blacksmith and the late Betsie Rabbitskin who ran our camps while on survey.

In addition, I would like to thank Moira Irvine and Nick Adams who prepared the maps; David Denton, Charles Martijn, Dr. Douglas Sutton, Dr. David Pokotylo, and Dr. William Morgan, and the Arctic referees, all of whom criticized various drafts of this paper; and my wife Nancy, who patiently assisted with the typing of many drafts.

The material in this paper presented on the Caniapiscau represents but a small portion of the research conducted in the region. Since 1978, Denton's work has continued along with additional studies on contemporary Cree camps in the region by Nicole Lafrance (Denton et al., 1981b). Further, the archaeological consulting firm of Archeotec, Inc. (1981, 1982), in collaboration with the Montagnais, has expanded research in the eastern branch of the reservoir. Consequently, as the manuscripts of these researchers join Latiberte's "Les schemes d'établissement cris de la Baie James" (1982) in print, a more comprehensive understanding of the Native use of Central Québec will be possible.

Though I owe these and many others a debt of gratitude for their kind assistance, the author accepts full responsibility for the contents of this paper.

\section{REFERENCES}

ARCHÉOTEC, INC. 1981. Recherches archéologiques sur les bassin du Lac Caniapiscau - 1980. On file at Service du Patrimoine Autochtone, Ministére des Affaires culturelles, Québec. 163 p.

1981. Presence Montgnais sur le bassin de la Caniapiscau: recherches archéologiques - 1981. On file at Service du Patrimoine Autochtone, Ministére des Affairs culturelles, Québec. 210 p.

BINFORD, L. 1978. Nunamiut Ethoarchaeology. New York: Academic Press. $509 \mathrm{p}$.

DENTON, D. 1977. An Archaeological Survey in the Vicinity of Lake Caniapiscau. On file at Service du Patrimoine Autochtone, Ministére des Affairs culturelles, Québec. 105 p.

1978. Preliminary Report on an Archaeological Survey in the Vicinity of the Future Caniapiscau Reservoir (Lakes Brisay, Marsilly, and Delorme). On file at Service du Patrimoine Autochtone, Ministére des Affairs culturelles, Québec. 104 p.

FERDAIS, M., PINTAL, J-Y., ROCHELEAU, C. BOUCHARD, M., and GREGOIRE, P. 1981a. Investigations archéologiques dans la région du Futur Réservoir Caniapiscau. Rapport Préliminaire - 1979. Direction générale du patrimoine Interventions Archéologiques, No. 1. Québec: Ministére des Affaires culturelles. 393 p

DENTON, D., LAFRANCE, N., PINTAL, J-Y., PILON, J-L, and EMARD, B. 1981b. Recherches archeologiques dans la région du Futur Réservoir Caniapiscau, Été 1980. On file at Service du patrimoine Autochtone, Ministere des Affairs culturelles, Québec.

HANKS, C. 1979. Preliminary Report on an Archaeological Survey in the Vicinity of the Future Caniapiscau Reservoir (Lakes Male Otter, Ice Bound, Tournon, Lantagnac, Clairambault, Poree, D'Espery, Vermeulle, Duplanter, and the Caniapiscau River). On file at Service du Patrimoine Autochtone, Ministére des Affaires culturelles, Québec. 333p.

LALIBERTE, M. 1982. Les schèmes d'établissement cris de la Baie James. Dossier 54, Direction Générale du Patrimoine, Ministére des Affairs culturelles, Québec. $116 \mathrm{p}$.

MOUSSETTE, M, 1979. La Pêche sur de Saint Laurent: repertoire des méthodes et des engins de capture. Montréal: Boréal Express.

PILLING, A. 1968. A use of historic sources in archaeology: an Indian earthworks near. Mt. Clemens, Michigan. Ethnohistory 15(2):152-203.

ROGERS, E. 1963. Notes on lodge plans in the Lake Indicator area of southcentral Québec. Arctic 16(4):219-227.

TANNER, A. 1978. Ethno-archaeology in the region of the James Bay Project. On file at Service du Patrimoine Autochtone, Ministére des Affaires culturelles, Québec. 43 p.

1980. Bringing Home Animals: Religious Ideology and Mode of Production of the Mistassini Cree Hunters. St. John's: Social and Economic Studies No. 23, Institute of Social and Economic Research, Memorial University of Newfoundland.

STEWARD, J. 1942. The direct historic approach to archaeology. American Antiquity 7(4):337-343.

WRIGHT, J.V. 1968. The boreal forest. In: Beals, C. S. and Shenstone, D.A. (eds.). Science, History and Hudson Bay. Vol. 1. Ottawa: Department of Energy, Mines and Resources. 55-68. 